\title{
THE COST PERFORMANCE AND CAUSES OF OVERRUNS IN INFRASTRUCTURE DEVELOPMENT PROJECTS IN ASIA
}

\author{
Jelena M. ANDRIĆ1, Abdul-Majeed MAHAMADU ${ }^{2}$, Jiayuan WANG ${ }^{1 *}$, \\ Patrick X. W. ZOU ${ }^{3}$, Ruoyu $\mathrm{ZHONG}^{4}$ \\ ${ }^{1}$ College of Civil Engineering, Shenzhen University, Shenzhen, China \\ ${ }^{2}$ Department of Architecture and the Built Environment, University of the West of England, Bristol, UK \\ ${ }^{3}$ Department of Civil and Construction Engineering and Center for Sustainable Infrastructure, \\ Swinburne University of Technology, Melbourne, Australia \\ ${ }^{4}$ China Center for Special Economic Zone Research, Shenzhen University, Shenzhen, P.R. China
}

Received 07 July 2018; accepted 07 January 2019

\begin{abstract}
Infrastructure plays a major role in the economic development of countries, especially in Asia which has experienced tremendous growth in recent years. The procurement of infrastructure continues to be characterized by cost overruns resulting in significant academic interest and theoretical propositions on the influential factors. This study contributes to this issue through adoption of pragmatic research methodology involving deterministic statistical analysis of real project data from reports as well as a qualitative analysis of these reports to unearth underlying issues from a thematic analysis. Furthermore, the study design takes a multi-country view towards establishing the role of contextual and geographical influences on cost overrun. An evaluation of 102 major infrastructure projects was performed covering railways, roadways and energy sectors in different regions in Asia. Findings reveal that differences in the propensity for cost overrun are mostly dependent on a type of infrastructure with rail projects being the most likely to overrun budget. Theoretically, propositions on the influence of project contextual factors are tested highlighting the influence of project size, project type, geographical locations, and the length of implementation period of a project as well as factors related to political, economic, strategic, and competence in infrastructure delivery which vary across countries.
\end{abstract}

Keywords: infrastructure projects, cost overruns, project type, geographical location, project size, implementation period, Asia.

\section{Introduction}

Infrastructure is essential for modern societies to enable the undisrupted flow of goods, energy, information, and people. Many governments have invested huge amounts of capital in infrastructure projects and programs in order to contribute to socio-economic development and prosperity of their country. Due to complexity, large-scale, long duration, high investment and longitudinal site conditions, infrastructure projects are exposed to higher risks than traditional construction projects which could lead to cost overruns (Wang \& Yuan, 2011). The definition of cost overrun provided by Flyvbjerg et al. (2018) is following: "Cost overrun is the amount by which actual cost exceeds estimated cost, with cost measured in the local currency, constant prices and against a consistent baseline". The current literature indicates that cost overruns have occurred in a significant number of infrastructure projects, such as Norwegian roadway projects (Odeck, 2004), road projects in the USA (Ellis, Pyeon, Herbsman, Minchin, \& Molenaar, 2007), transport projects in Slovenia (Makovšek, Tominc, \& Logožar, 2012), highway projects in Australia (Terrill \& Danks, 2016), railway projects in Australia (Love, Zhou, Edwards, Irani, \& Sing, 2017), and others.

In the previous studies, the project performance is analysed commonly for developed countries in Europe, USA, and Australia, but the number of research that focuses on the developing countries is limited. Secondly, the results from research conducted by Flyvbjerg, Skamris Holm, and Buhl (2002), Flyvbjerg, Skamris Holm, and Buhl (2003a), Flyvbjerg, Bruzelius, and Rothengatter (2003b), Flyvbjerg, Skamris Holm, and Mand Buhl (2004), in which a large

${ }^{\star}$ Corresponding author. E-mail: wangjy@szu.edu.cn 
sample of projects located in a wide geographical area covering five continents cannot be apply for specific area or country. Since the geography matters for cost overruns which are concluded by Cantarelli, Flyvbjerg, and Buhl (2012c), the findings for cost performance of projects in Europe could not be applied to Asian countries (Huo et al., 2018). Besides, the focus of previous studies was on the cost performance of transportation projects, railways, roadways, bridges, and tunnels. However, other types of infrastructure projects such as power supply systems, water supply are not considered.

When causes of cost overruns and key risks in the construction industry are considered, questionnaire surveys and interviews are common methodology which is applied in a significant number of the current research (Zhao, Hwang, \& Yu, 2013; El-Sayegh \& Mansour, 2015). However, the obtained results from questionnaire surveys and interviews are based on subjective judgment and the results are less reliable due to a different background of respondents.

In order to close these gaps in the current literature, the aims of this study are: (1) to determine the cost performance of infrastructure projects in developing countries in Asia; (2) to examine the four independent variables: geographical location, project type, project size and length of project implementation period and their influence on cost overrun; (3) to investigate the performance of energy sector projects since this type of projects haven't been studied earlier; and (4) to identify causes of cost overruns in Asia. To provide more reliable information about cost overruns, the focus is to identify causes of overruns from real case data. A sample of 102 infrastructure projects in Asia is analysed and the characteristics of cost performance are measured by statistical methods. The studied sample includes railways, roadways, and energy sector projects located in four Asian regions. Compared to other studies, this sample includes additional type of infrastructure, energy sector projects. Further, causes of cost overruns in these projects are extracted from the project completion reports which are collected from the website of the Asian Development Bank.

\section{Literature review}

\subsection{Literature review on cost performance of infrastructure projects}

A study on cost overruns in transport projects is conducted by Flyvbjerg et al. (2002, 2003a, 2003b, 2004). The performance of 258 projects located in Europe and North America are investigated and different probabilistic and statistical tools (F-test, Welch t-test, regression analysis and other) for this analysis are applied. The obtained results designate that the average cost overrun of the studied sample is $28 \%$. Regarding the project type, rails projects are more prone to cost overruns with average cost escalation of $44.7 \%$, followed by fixed-links with $33.8 \%$ and roads projects with $20.4 \%$. Also, the geographical location of projects is of importance for cost escalations, while there is no statistically significant result for the year of a decision to build. In addition, Flyvbjerg et al. (2004) investigated the dependence between cost escalation and three independent variables: (1) size of the project; (2) type of project ownership; and (3) length of the project implementation period. They have concluded that: (1) cost escalation is influenced by the length of implementation period; (2) in case of bridges and tunnels, larger projects have resulted in higher percentage of cost overruns; and (3) there is no significant impact between the type of ownership and cost performance of projects.

Similar research was conducted for road projects in Norway, in which Odeck (2004) have estimated that the mean cost overruns of these projects are $7.9 \%$, with the range between $-59 \%$ and $183 \%$. For Norwegian roads projects, cost overrun was higher for smaller size projects compared to larger projects. Also, completion time and different locations are found to have an effect on cost overruns. Further, Lee (2008) has carried out research on the cost overruns of capital projects in Korea. The dataset included road, rail, airport and seaport projects. The findings from his study have indicated that rail projects contribute to a major proportion of total cost overruns; $100 \%$ of rail projects have a maximum cost overrun of $50 \%$, while $95 \%$ of road projects have a maximum cost overrun of $50 \%$. In another study in Asia, the cost overruns of 35 transport projects (harbours and ports, roads, railways, bridges and subway projects) varied between $98.23 \%$ and $0.83 \%$ (Park \& Papadopoulou, 2012).

Cantarelli, Molin, van Wee, and Flyvbjerg (2012a) have conducted a study with the focus on cost performance of large-scale transport projects in the Netherlands since the results from previous studies are not relevant for a specific country. The average cost overruns in Dutch transport infrastructure projects was $16.5 \%$. The findings from this study highlight the fact that the frequency and magnitude of cost overruns are higher in the pre-construction phase compare to the construction phase. Further, Cantarelli, van Wee, Molin, and Flyvbjerg (2012b) have examined the influence of three independent variables project type, project size and the length of the implementation period on the cost overruns in Dutch infrastructure projects. For data analysis, probabilistic and statistical methods, such as Binominal test, Paired sample T-test, F-test, One-way ANOVA are used. The obtained results have shown that the average cost overruns for different project types in the Netherlands are: $21.7 \%$ for fixed-links, $18.6 \%$ for roads and $10.6 \%$ for rails. Other significant conclusions from this study are: (1) the length of preconstruction phase is significant since cost increases by $5 \%$ with each additional year in preconstruction period; and (2) cost overrun slightly depend on project size. In order to prove the hypothesis that the size of cost overruns varies with geographical location, Cantarelli et al. (2012c) have tested the performance of transport projects in the Netherlands versus worldwide. The conclusion was that cost overruns in Netherland were smaller compared to worldwide and project performance was significantly higher than in other parts of the world. 
Additionally, they proved that geographical location influence cost overruns in a significant matter.

Recently, Huo et al. (2018) have conducted research on the cost performance of mega transport projects in Hong Kong. The influence of three descriptive variables, project size, project type and the length of implementation period on cost overrun is examined through different statistical tests including Binominal test, T-test, F-test, One-way ANOVA, Two-way ANOVA and regression analysis. From their study, it is concluded: (1) the average cost overrun of transport projects in Hong Kong is $39.18 \%$; (2) rail projects are more prone to cost escalation compared to fixedlink and roads projects; and (3) there is no significant statistical relation between project size and year of decision to build on cost overruns.

\subsection{Literature review on causes of cost overruns}

The causes of cost overruns vary for different projects depending on their geographical locations, type, project size and other. For capital investment projects in Korea, the key causes of cost overruns were changes of project scopes, unexpected changes in a construction environment, delay of construction, irrational estimation and adjustment of project cost and no practical use of the earn value management (Lee, 2008). Among the causes of cost overruns in transport infrastructure projects in Asia, the lowest bidder is identified as the most significant cause, while lump-sum contracts had the greatest influence on the occurrence of cost overruns (Park \& Papadopoulou, 2012).

The seven most frequent causes which are leading to cost overruns in projects according to Merrow (2011) are: poor bidding phase, insufficient risk allocation, unrealistic cost estimations, reduction in the upfront cost and leading to poor quality, pressure to reduce construction time and increase net present value, excessive pressure on project manager, and greed.

Cantarelli, Flybjerg, Molin, and van Wee (2013) have investigated the causes of cost overruns in construction projects by literature review and categorize them into 4 main explanations for cost overruns: technical, economic, psychological and political. Technical explanations for cost overruns are error in forecasting price, poor design and implementation, changes in scope, inappropriate organizational structure, inadequate decision-making, and planning process. For economical explanations, lack of resources, inefficient use of resources, dedicated funding process, poor contract management, and strategic behaviour are outlined. Psychological explanations are based on the optimism bias among local officials and cognitive bias of people. The main explanations for cost overruns due to political causes are deliberately underestimated in order to increase the chance of acceptance, strategic misrepresentations including lack of discipline, lack of commitment, lack of coordination, political pressure and unbalanced information.

\section{Methodology}

\subsection{Data collection}

The data about infrastructure projects is collected from Asian Development Bank (ADB). ADB has archived Project Completion Reports, which contain detailed information about estimated cost, actual cost, duration, causes of cost escalation and schedule delays (ADB, 2019). The sample presents development projects financed by ADB. In total, it consists of 102 infrastructure projects which year of a decision to build is in the period between 1987 and 2011. This sample is chosen based on data availability from $\mathrm{ADB}$. The data is extracted from the completion reports and organized in the following sequence: name of project, country, region, project type, year of a decision to build, appraisal cost, actual cost and cost overrun. Infrastructure projects are located in four regions in Asia: East Asia, Central Asia, South Asia, and Southeast Asia. The number of projects per regions and the number of each projects type is summarized in Table 1. The majority of projects are originated from East Asia (China) since Chinese construction market in the largest in Asia. Additionally, China is the biggest developing country in the World, in which the rapid growth of the economy has led to massive infrastructure development (Zeng, C. M. Tam, Deng, \& V. W. Tam, 2003). Most infrastructure projects are roadways followed by energy sector projects. In sum, the actual costs of these projects are US\$ 69592.083 million.

Table 1. Project data statistics

\begin{tabular}{|l|c|l|c|}
\hline \multicolumn{1}{|c|}{ Regions } & $\begin{array}{c}\text { Number of } \\
\text { projects }\end{array}$ & Project types & $\begin{array}{c}\text { Number of } \\
\text { projects }\end{array}$ \\
\hline East Asia & 44 & Railways & 19 \\
\hline Central Asia & 21 & Roadways & 56 \\
\hline South Asia & 21 & Energy Sector & 27 \\
\hline Southeast Asia & 16 & & \\
\hline
\end{tabular}

\subsection{Selections of four variables for cost overruns}

In previous studies, authors have analysed the influence of three different variables on the cost performance in infrastructure projects. In studies by Flyvbjerg et al. (2003a), they have investigated the dependence of cost overruns for three variables, project type, project size and type of project ownership. Similarly, Cantarelli et al. (2012b) and Huo et al. (2018) have determined the influence of three variables: project type, project size and the length of implementation period for Dutch projects and projects in Hong Kong, respectively. Beside three variables, geographical location of projects as an additional variable is employed to examine its influence on the size of cost overruns in this study. Thus, four variables are selected since previous studies have shown that cost overruns were dependent on them.

The definition of four independent variables and the corresponding assumptions are as follows. 
Project type. In the previous study, the focus was on cost overruns in transport infrastructure projects (roads, rails, and fixed-links). However, infrastructure projects related to the energy sector are additionally included in this study due to the lack of data on fixed-links projects. The cost performance varies for different kinds of infrastructure projects according to findings by Flyvbjerg et al. (2003a), Cantarelli et al. (2012a) and Huo et al. (2018). So, this study assumes that there is a difference in cost overruns based on the project type.

Geographical location. Since the Asian continent is spacious and infrastructure projects are located in different parts, the cost performance of projects for different parts of Asia is analysed independently. Consequently, geographical location is adopted as a variable for examining the cost performance in different parts of Asia. According to the project location, four different regions can be distinguished: East Asia, Central Asia, South Asia, and Southeast Asia. This study assumes that the projects in different parts of Asia have different cost overruns based on the fact that cost overruns vary depending on country and region according to Cantarelli et al. (2012c). Therefore, this study assumes that there is a difference in cost overruns for different regions.

Project size. The size of a project is defined as an estimated cost at the time of the decision to build. In previous studies, the statistical relationship between the project size and cost overruns are investigated. According to Flyvbjerg et al. (2003a), there was a correlation between the project size and cost overruns for fixed-links projects. Also, Odeck (2004) have highlighted that smaller projects are exposed to higher cost overruns compared to bigger projects. Consequently, the influence of project size on the cost overruns is investigated and determined in this study.

The length of project implementation period. There was a significant statistical relationship between the cost overrun and the length of implementation phase in studies by Flyvbjerg et al. (2003a), Cantarelli et al. (2012b) and Huo et al. (2018). In addition, Cantarelli et al. (2012a) have shown that there is a statistical dependence between the cost overrun and different project phases (pre-construction phase and construction phase). The implementation phase of a project is defined as the time period between the year of formal decision to build and the time when construction is completed (Flyvbjerg et al., 2004). Thus, the statistical relationship between the length of the implementation phase and cost overruns are examined in this study.

\subsection{Methods for data analysis}

In literature, there are several definitions for cost overrun provided by different scholars. Cost overrun is defined as a difference between the actual cost which represents cost determined at the time of project completion and estimated costs determined at the time of formal decision to build (Flyvbjerg et al., 2002; Odeck, 2004; Love, Sing,
Wang, Irani, \& Thwala, 2014). Cost overruns are calculated by the following equation:

$$
\text { Cost overrun }=\frac{\text { Actual costs }- \text { Appraisal costs }}{\text { Appraisal costs }} \star 100 \%,
$$

where Actual costs are estimated after the project completion, Appraisal costs are determined at the time of formal decision to build.

If actual costs are higher than appraisal costs, then cost overrun has occurred and its value is expressed as a percentage point above $0 \%$. Otherwise, the project has experienced cost underrun and its value is expressed as a percentage point below $0 \%$.

To determine relations between four independent variables and cost overruns, probability and statistical methods and tests which include Binomial test, Mann-Whitney U-test, Fisher test (F-test), One-way ANOVA and linear regression analysis are applied. The binomial test is an exact test of the statistical significance of deviation from a theoretically expected distribution of observations into two categories and it tests the null hypothesis that two categories are equally likely to occur. In this study, the binomial test is applied to test whether projects with cost overruns and projects with cost underruns are equally likely to occur. Mann-Whitney U-test is a non-parametric alternative test which compares the means of two samples from the same population in order to exam their equality. This test is used to compare the mean value of projects with cost overruns and projects with cost underruns. Fisher test is a statistical test which compares statistical models that have fitted to a data set in order to identify a model that best fits the population. Practically, F-test is applied to test linear regression models which describe the relation between the year of a decision to build and cost overruns, project size and cost overruns and length of implementation period, and cost overruns. One-way ANOVA is a statistical test that compares the mean values of several samples. Hence, One-way ANOVA is used to compare the mean values of cost overruns for different types of infrastructure and cost overruns for projects in different geographical locations. While linear regression analysis is a statistical approach for modelling relationship between two independent variables. Specifically, the relationship between year of a decision to build and cost overruns, project size and cost overruns and the length of implementation and cost overruns are modelled by linear regression analysis. All statistical analyses are performed by Matlab, as well as all graphs are printed in Matlab. For identifying and analysing causes of cost overruns in projects in Asia, a qualitative method is used with the aid of software package NVivo12.

\section{Cost performance of infrastructure projects}

\subsection{Characteristics of cost performance of infrastructure projects in Asia}

In the observed sample, the occurrence of cost overruns is as following: 


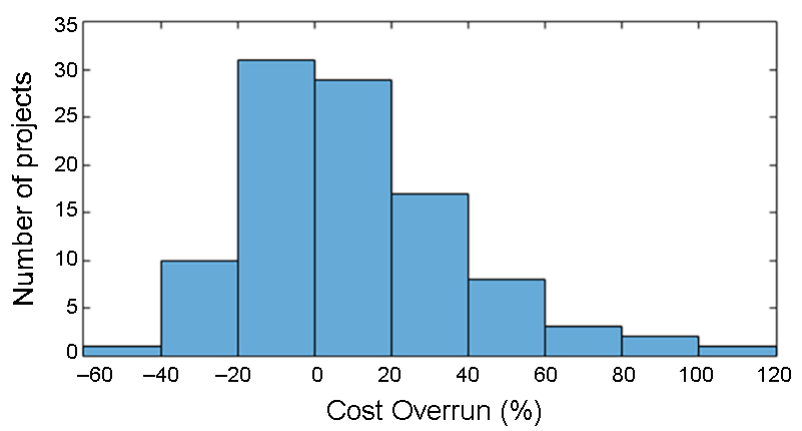

Figure 1. Histogram of cost overruns of infrastructure projects in Asia

- $56.86 \%$ of projects experienced cost overrun; $2 \%$ of projects completed on budget; and $41.18 \%$ of projects were cost underrun;

- projects with cost overruns are as common as projects with cost underruns ( $\mathrm{p}=0.0226$, Binomial test); and

- the average cost overrun is $26.24 \%(\mathrm{SD}=25.63)$ in projects with cost overruns and the average cost underrun is $-12.24 \%(\mathrm{SD}=12.25)$ in projects with cost underrun (Mann-Whitney U-test, $\mathrm{U}=0.00$, $\mathrm{p}<0.0001)$.

Further, a histogram of cost overruns distribution in infrastructure projects is illustrated in Figure 1. Mathematically, the characteristics of cost overruns in infrastructure projects are as follows:

- the range of cost overrun is between $-47.91 \%$ and $111 \%$; and

- the mean value of cost overrun is $9.88 \%(\mathrm{SD}=28.12$ ).

In Figure 1, it can be noticed that ranges with cost overrun between $-20 \%$ and $0 \%$ and between 0 and $20 \%$ have the highest number of projects (31 and 29) compared to other bins in histogram. When these two bins of projects are considered more detailed, there were no different from other bins regarded to project type or specific geographical location or project size.

\subsection{Cost overrun over year of decision to build}

The performance of projects over the year of a decision to build is considered in order to examine whether there has been a change in the size of cost overrun over the years. A graph of cost overrun over year of a decision to build is depicted in Figure 2. From this graph, it is noticed that there is dependence between two parameters and linear regression analysis has verified this conclusion (F-test,

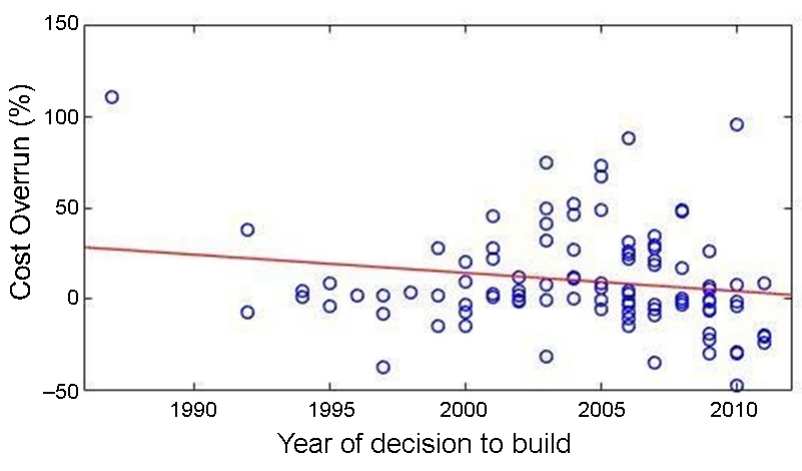

Figure 2. Cost overruns over year of decision to build

$\mathrm{F}=3.133, \mathrm{p}=0.0806)$. Analytically, the linear regression line for reduced cost overrun over the year of a decision to build is given as:

$$
\Delta C=-1.00496^{\star} Y+2024.0587,
$$

where $\Delta C$ is a cost overrun and $Y$ is the year of a decision to build.

This result highlights the fact that cost overruns in projects have reduced over years. Approximately, the reduction of cost overruns is $1 \%$ for every year in infrastructure projects in Asia.

\subsection{Cost overrun for different project types}

Cost overruns are examined for different projects types and the obtained results are as following: the mean value of cost overrun for railways is $21.11 \%$ ( $S D=39.78$ ), for roadways is $10.47 \%(\mathrm{SD}=26.05)$ and for the energy sector is $0.75 \%(\mathrm{SD}=18.97)$. The results indicate that the highest mean values of cost overruns occurred in railway projects (One-way ANOVA, $\mathrm{F}=3.071, \mathrm{p}=0.051$ ). On the other hand, energy sector projects have the lowest mean value of cost overruns since the average values of cost underrun projects is slightly higher than the average value of cost overrun projects (Table 2).

The average value and standard deviation of cost overruns and cost underruns for each project type are provided in Table 2. Considering different project types and their mean values of average cost overrun and average cost underrun, the main findings are as follows:

- Infrastructure projects with a cost overrun are as common as projects with cost underrun for rails projects (Binominal test, $\mathrm{p}=0.1762$ ), roads projects (Binominal test, $\mathrm{p}=0.0297$ ) and power sector projects (Binominal test, $\mathrm{p}=0.1295$ ).

Table 2. Average cost overrun and underrun for different type of projects

\begin{tabular}{|l|c|c|c|c|c|c|}
\hline \multicolumn{1}{|c|}{ Project type } & $\begin{array}{c}\text { Number of overrun } \\
\text { projects }\end{array}$ & Mean value & SD & $\begin{array}{c}\text { Number of underrun } \\
\text { projects }\end{array}$ & Mean value & SD \\
\hline Railways & 10 & $48.01 \%$ & 37.98 & 9 & $-8.77 \%$ & 5.45 \\
\hline Roadways & 34 & $24.05 \%$ & 26.13 & 21 & $-12.15 \%$ & 12.78 \\
\hline Energy Sector & 14 & $14.30 \%$ & 10.28 & 12 & $-14.99 \%$ & 14.91 \\
\hline Total & 58 & & 42 & & \\
\hline
\end{tabular}


- For projects with cost overruns, the mean value of cost overrun for rail projects is the highest mean value of cost overrun compared to roads projects and energy sector projects (One-way ANOVA, $\mathrm{F}=6.115$, $\mathrm{p}=0.003998)$.

- The mean value of cost overrun for railway project is the twice of the mean value of cost overruns for roadway projects (One-way ANOVA, $\mathrm{F}=5.999$, $\mathrm{p}=0.018562)$.

\subsection{Cost overrun for different geographical locations in Asia}

The geographical location of projects is an important variable since projects since the previous studies highlighted the fact that cost overruns of projects vary depending on their geographical location (country). The mean values of cost overruns with standard deviations are estimated for different locations in Asia. The obtained results for projects in a different location are following: the mean value of cost overrun in Central Asia is $-4.53 \%$ ( $\mathrm{SD}=18.10$ ), in East Asia is $22.04 \%$ ( $\mathrm{SD}=27.90)$, in South Asia is $0.79 \%$ $(\mathrm{SD}=22.53)$ and in Southeast Asia is $7.31 \%(\mathrm{SD}=33.68)$. For different regions in Asia, the main findings are:

- The highest mean value of cost overrun is in East Asia compared to other parts of Asia (One-way ANOVA, $\mathrm{F}=6.4078, \mathrm{p}=0.0005)$.

- Projects in Central Asia were cost underrun, which is not typical for infrastructure projects.

Since the majority of railway projects (14 of 19 projects) are located in East Asia and they have experienced the highest cost overruns among other projects types, it is one of the factors which contribute to high cost overruns in this region. Secondly, projects in Central Asia are cost underrun, which is uncommon for infrastructure projects.

In order to obtain more detailed information about cost overruns and underruns in infrastructure projects in Asia, the average cost overruns and underruns with standard deviations for regions in Asia is shown in Table 3. In the case of Central Asia, the majority of projects, 13 of 21 projects were cost underrun, which contributed to the negative value of total cost overrun for this region. To provide explanations of cost underruns in Central Asia, the project completion reports are reviewed and the identified causes for cost underruns are as following: the scope of civil works was reduced in some projects, the cost of equipment was lower than actual, the cost of civil works and consulting services were lower in some projects, and no cost incurred for land acquisition and resettlement in some projects.

Further, the main conclusions which can be drawn considering the average value of cost overrun and underrun in different regions in Asia are:

- The results show that the projects with a cost overrun are as frequent as projects with cost underrun for every region, East Asia (Binominal test, $\mathrm{p}=0.00004$ ), Central Asia (Binominal test, $\mathrm{p}=0.0258$ ), South Asia (Binominal test, $\mathrm{p}=0.1401$ ), and Southeast Asia (Binominal test, $\mathrm{p}=0.1963$ ).

- There is no significant difference between the average cost underrun for projects in Central Asia and South Asia (One-way ANOVA, $F=0.71558, \mathrm{p}=0.402629$ ).

\subsection{Cost overrun over project size}

To investigate the statistical relationship between the project size and cost overrun, the linear regression analysis is performed. There is a correlation between the project size and cost overruns (F-test, $F=39.4116, p=0.000$ ). The plot of cost overrun over project size with the regression line is shown in Figure 3. Mathematically, the regression line for all projects is given by the following equation:

$$
\Delta C=0.0126^{\star} E+1.2842,
$$

in which $\Delta C$ is a cost overrun and $E$ is the estimated cost at the time of the decision to build.

Further, cost overruns over project size are examined for different projects types and regions, separately. Based on linear regression analysis, there is a linear correlation between project size and cost overrun for all types of projects, rails projects (F-test, $\mathrm{F}=8.4679, \mathrm{p}=0.003887$ ), roadways projects (F-test, $\mathrm{F}=13.6582, \mathrm{p}=0.000513$ ), and

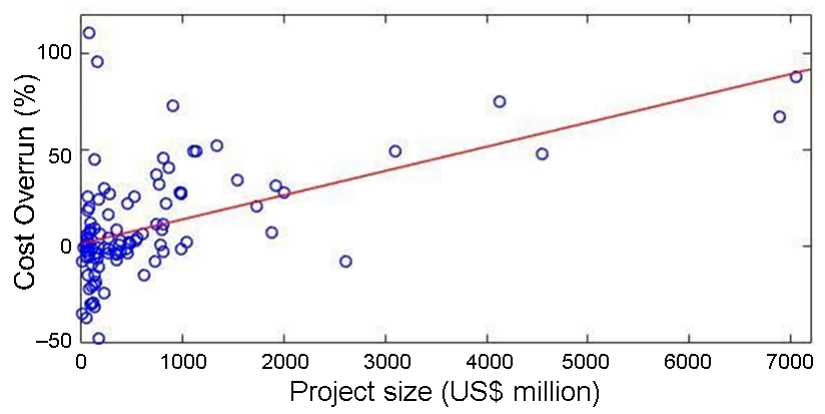

Figure 3. Cost overrun over project size for all projects

Table 3. Average cost overrun and underrun for different regions in Asia

\begin{tabular}{|l|c|c|c|c|c|c|}
\hline \multicolumn{1}{|c|}{ Location } & $\begin{array}{c}\text { Number of overrun } \\
\text { projects }\end{array}$ & Mean value & SD & $\begin{array}{c}\text { Number of underrun } \\
\text { projects }\end{array}$ & Mean value & SD \\
\hline East Asia & 35 & $29.32 \%$ & 26.71 & 9 & $-6.30 \%$ & 4.00 \\
\hline Central Asia & 6 & $14.76 \%$ & 11.52 & 13 & $-14.14 \%$ & 14.19 \\
\hline South Asia & 9 & $20.79 \%$ & 16.25 & 12 & $-14.15 \%$ & 12.54 \\
\hline Southeast Asia & 8 & $27.58 \%$ & 35.82 & 8 & $-12.96 \%$ & 14.45 \\
\hline Total & 58 & & & 42 & & \\
\hline
\end{tabular}




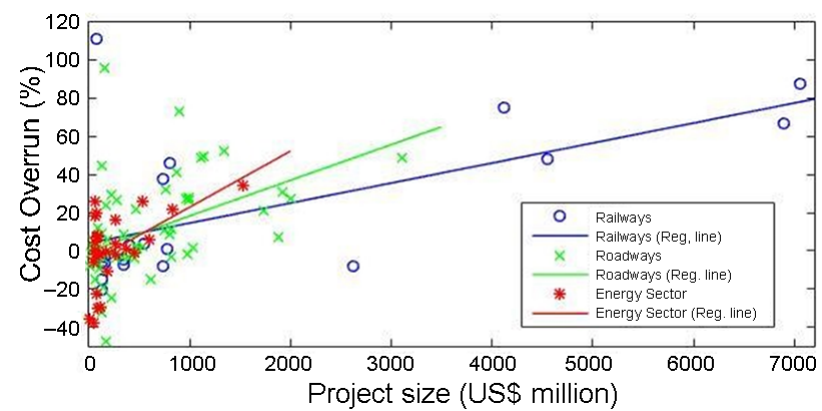

Figure 4. Cost overrun over project size for different projects type

energy sector projects (F-test, $\mathrm{F}=8.72317, \mathrm{p}=0.006749$ ). A graph of cost overrun over project size for rails, roads, and energy sector projects with regression line is illustrated in Figure 4. Statistically, the regression line for rails projects is:

$$
\Delta C=0.0105^{\star} E+4.12776 .
$$

In the case of the roads projects, the equation of the regression line is:

$$
\Delta C=0.0187^{\star} E-0.33008 .
$$

For energy sector projects, the relationship between the cost and cost overruns is:

$$
\Delta C=0.02948^{\star} E-6.39315 \text {. }
$$

Subsequently, regression analysis is performed for projects in different Asian regions in order to determine whether there is a correlation between cost overrun and project size for a particular region. There is a significant statistical effect between project size and cost overrun for two regions: East Asia (F-test, $\mathrm{F}=19.7756, \mathrm{p}=0.00006$ ) and South Asia (F-test, $\mathrm{F}=14.2150, \mathrm{p}=0.00129)$. The linear regression lines for East Asia and South Asia is illustrated in Figure 5. On contrary, there is no influence between project size and cost overruns in Central Asia (F-test, $\mathrm{F}=0.0329, \mathrm{p}=0.8579$ ) and Southeast Asia (F-test, $\mathrm{F}=0.5272, \mathrm{p}=0.4797)$. Mathematically, the linear regression formula for projects in East Asia is following:

$$
\Delta C=0.00991^{\star} E+9.23298 .
$$

The equation of the linear regression line for projects in South Asia is:

$$
\Delta C=0.0479^{\star} E-13.63298 \text {. }
$$

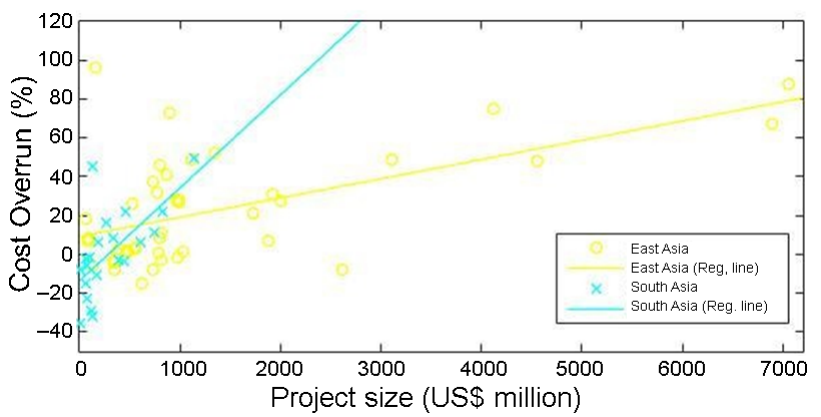

Figure 5. Cost overrun over project size for different regions

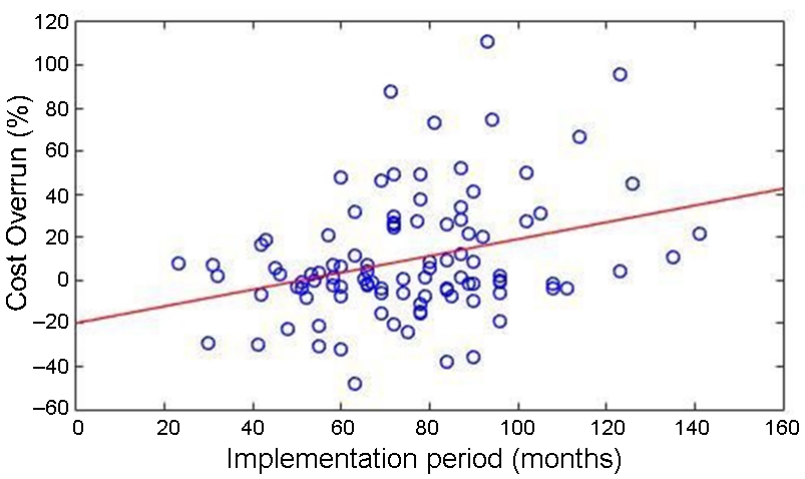

Figure 6. Cost overrun over implementation period

\subsection{Cost overrun over implementation period}

The effect of the length of the implementation period on cost overrun is checked by regression analysis. Results confirm that there is a correlation between this variable and cost overruns (F-test, $\mathrm{F}=11.2495, \mathrm{p}=0.0011$ ) and the dependence between these two statistical variables is shown in Figure 6. Also, this conclusion is in line with the previous findings from Cantarelli et al. (2012b) and Huo et al. (2018). Statistically, the linear regression model for the length of the implementation period is provided as:

$$
\Delta C=0.3948^{\star} T-19.841,
$$

where, $\Delta C$ is a cost overrun and $T$ is the implementation period.

Firstly, the relation between the implementation period and cost overrun is tested for different project types. Taking into account different project types, results show there is a statistical dependence between implementation period and cost overrun for rail projects (F-test, $\mathrm{F}=3.3374$, $\mathrm{p}=0.08533$ ) and road projects (F-test, $\mathrm{F}=10.7078$, $\mathrm{p}=0.0018)$. On the other hand, there is no significant statistical effect according to regression analysis for energy sector projects (F-test, $\mathrm{F}=0.26017, \mathrm{p}=0.6145$ ). Figure 7 displays a graph of the cost overrun over the implementation period with a regression line for rail and road projects. Mathematically, equation of the obtained regression line in case of rail project is:

$$
\Delta C=0.84879^{\star} T-41.476 .
$$

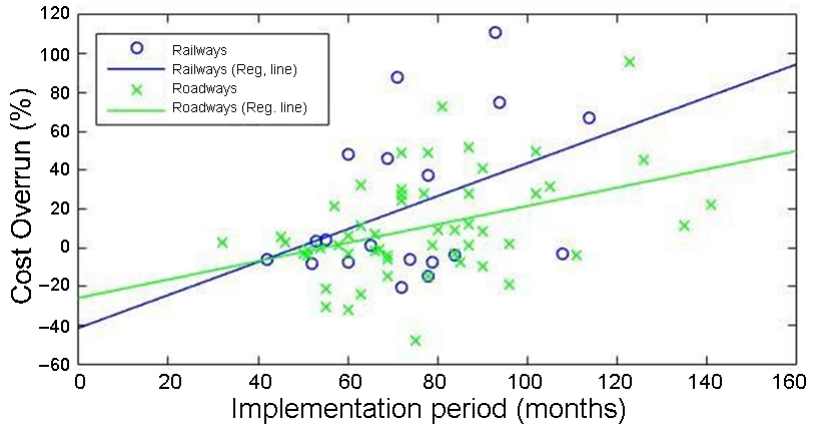

Figure 7. Cost overrun over implementation period for different project types 


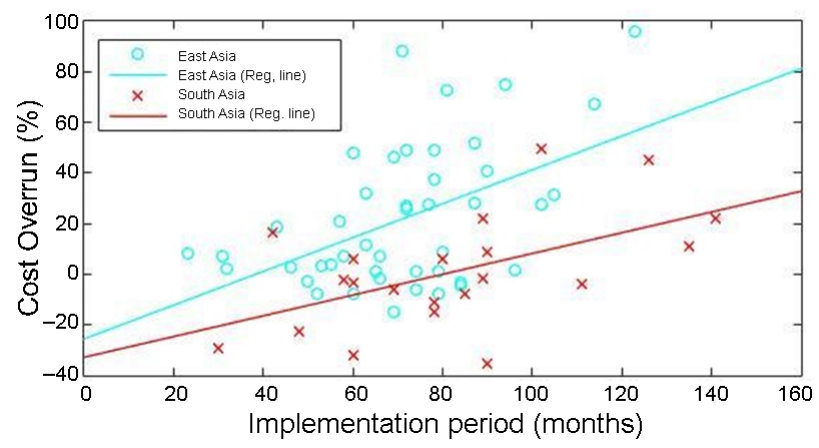

Figure 8. Cost overrun over implementation period for different regions

In the case of road projects, the regression analysis model is as following:

$$
\Delta C=0.47336^{\star} T-25.967 .
$$

Considering the relation between cost overrun and implementation period for different geographical locations by performing regression analysis, the results have shown that there is no correlation for projects in Central Asia (F-test, $\mathrm{F}=0.9055, \mathrm{p}=0.3532$ ), and Southeast Asia (F-test, $\mathrm{F}=0.2146, \mathrm{p}=0.6503)$. On the other hand, there is a statistical relationship between the implementation period and cost overrun based on regression analysis for projects in East Asia (F-test, $F=13.8065, \mathrm{p}=0.0005)$ and South Asia (F-test, $\mathrm{F}=7.7515, \mathrm{p}=0.0118$ ). Figure 8 depicts a plot cost overrun over the length of the implementation period with a regression line for projects in East Asia and South Asia. Analytically, the equation of the regression line for projects in East Asia is:

$$
\Delta C=0.6683^{\star} T-25.5654 .
$$

Moreover, the regression line for projects in South Asia is:

$$
\Delta C=0.4101^{\star} T-32.8229 .
$$

\section{Causes of cost overruns}

The detailed description of cost overruns in each infrastructure projects is provided in the Project completion reports from $\mathrm{ADB}$. Using the reports, qualitative data analysis is performed in order to identify the causes which contributed to cost overruns in 58 projects. For a qualitative data analysis, NVivo12 software is used since it is suitable for performing qualitative data analysis such as coding and categorization (Adu, 2015). Causes from reports which contributed to cost overruns in each project are coded into nodes. For different causes, a new node is created. Some of the causes have repeated simultaneously in more than one project. In total, 9 nodes are coded presenting 9 causes of cost overruns which appear across 58 projects. Causes of cost overruns are complex geological and geotechnical conditions, land acquisition and resettlement, consulting services, changes in currency exchange rate, change in design specifications, safety, and environmental protection, resources (construction materials, equipment and labour), construction works, and fluctuations in an interest rate.

In order to provide details about the frequency of causes in infrastructure projects, nodes compared by a number of coding references is performed as described in Figure 9. A diagram for nodes compared by a number of coding references is based on tree map analysis. A tree map is a hierarchy chart that shows hierarchical data as a set of nested rectangles of various sizes and it is used to represent the amount of coding at each node. The size of the rectangle presents the amount of coding references. According to Figure 9, the most frequent causes of cost overruns are resources (construction material, equipment and labour), construction works, changes in design, land acquisition and resettlement and changes in currency exchange rate.

Resources including construction material, different kind of equipment and labour are the most common cause of

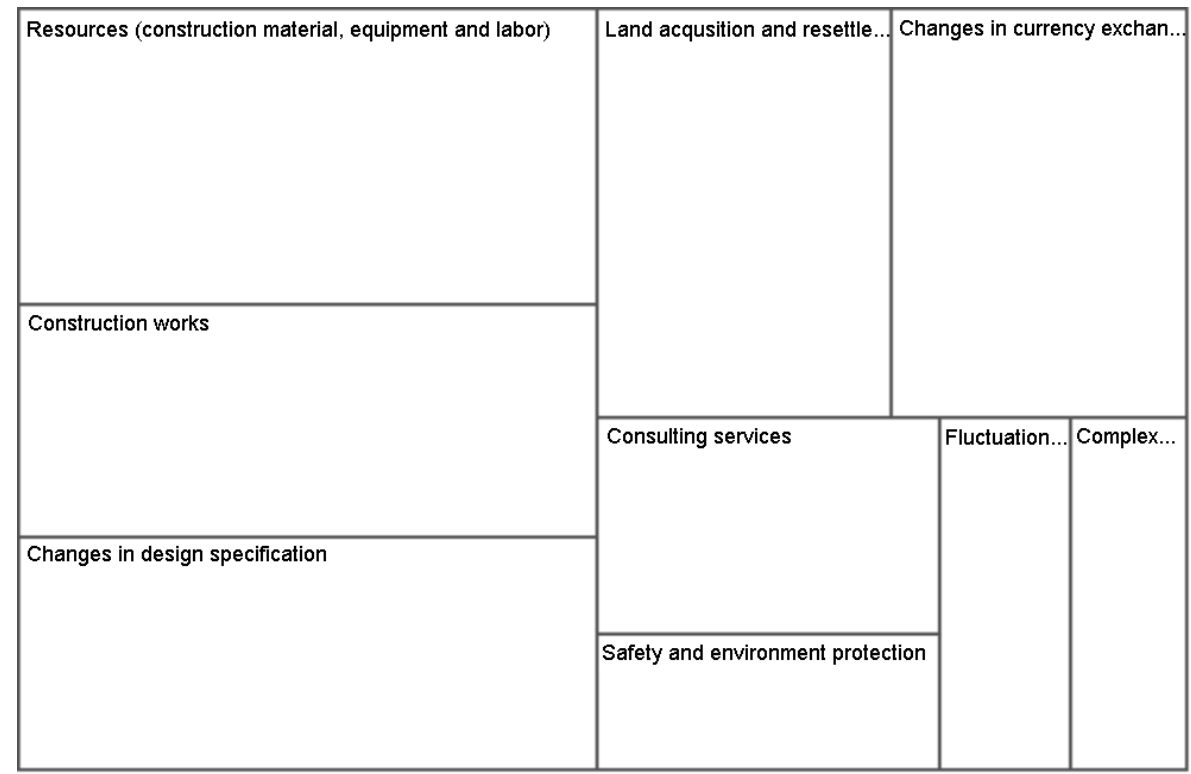

Figure 9. Nodes compared by number of coding references 
cost overruns in infrastructure projects in Asia. The increased cost of construction materials, increased cost of equipment, additional equipment, and increased cost of labour significantly contribute to overruns in the majority of projects. The fluctuation in the prices of construction materials appears due to the inflation rate and relation between supply and demand in the construction market (Wang \& Yuan, 2011). In previous studies, the increased cost of construction materials is one of the critical risks which affect the construction market in China. Cost overrun due to the increased cost of equipment, fuel, gas and oil has appeared in some development projects. Since infrastructure projects are lengthy projects, during their implementation period the cost of equipment, fuel, gas and oil increases. The demand for equipment, fuel, gas and oil and the current number of construction projects influence the price on the construction market. Similarly to the increased cost of materials and equipment, the increased cost of labour is a significant factor which depends on the demand for labour on the construction market.

The main causes for the increased cost of construction work in infrastructure projects are complex conditions at the construction site, contract prices higher than estimated, longer than estimated construction period, increased scope of works, contract variations during construction, deterioration of road conditions, and changes in road grade which increases earthworks. Also, high inflation leads to a rapid rise in construction work.

Changes in design specifications include addition of structure elements on the route such as bridges and tunnels, interchanges, overpasses and underpasses, access roads for expressways, additional sub-transmissions for power supply projects, increased length and height of bridges and tunnels, enhanced anti-seismic measures for structures, and fund for research and development of technologies for project design. In the case of railway projects, design modifications in railway projects are required in order to cope with topography, build elevated track structure to avoid using arable land for railway construction and ensure safety, provision of additional facilities for connecting with other railway lines, upgrade of welded rail, additional environment work of "green environment corridor", increased size and capacity of passengers stations, upgrading of key design standards, optimize construction design, ensure the construction quality, additional railway station on the route, and a large number of irrigation culverts to meet the needs of farmers along the railway. Before designing, the proposed route should be investigated in details, as well as soil conditions.

Land acquisition and resettlement is one of the frequent causes of cost overruns in projects in Asia. With the rapid economic growth and urbanization in Asia, there is a great demand for land. Similarly to the previous risk, increased cost of land acquisition and resettlement has affected mostly infrastructure projects in China. In the past 56 years, more than 700 million resettles have occurred in China due to large-scale economic growth and land acquisition for development and real estate (Shi, Zhou, \&
Yu, 2012). The resettlement plans for railway projects in China were prepared by the Ministry of Railway and were implemented according to the 1998 Land administration Law for earlier projects and the 2004 Land Administration Law with the following government rules, regulations, and agreements for later projects. The aim of China's resettlement policy is to reduce the use of occupied land for infrastructure and reduce the number of displaced persons. Further, the general principles of policies on project resettlements are the following: economic compensation, social mobilization, preferential government policy, support from the various partners, and development of resources. In China, compensation for land acquisition and resettlement is a one-time lump sum, in which compensation for land, houses, greenhouses, toilets, stalls, crops, and resettlement subsidies is included (Qian, 2015). The increased cost of land acquisition occurs due to higher land compensation rates, incremental cost for house and building relocation, relocation of electricity and communication lines, more affected people, more extensive demolition of houses and infrastructure, larger areas of land acquired for incremental access roads, and permanent acquisition of unrecoverable land for temporary use.

Consulting services are important for large-scale infrastructure projects from this case study. Usually, causes related to consulting services which contribute to cost overruns are higher cost and engagement of more comprehensive consulting services than planned and longer duration of a project.

Causes of cost overruns related to safety and environmental protection are associated with safety and operation management, security issues and environmental protection of the site. Some countries in Asia are situated in complex geopolitical regions, in which political, ethnic and religious conflicts are common, such as Afghanistan and Pakistan. In one of the studied projects, a terrorist attack occurred on the construction sites and it resulted in casualties, temporary suspension of the current civil works, and higher project cost. Therefore, a force majeure is an important factor in unstable geopolitical regions in Asia.

Change in currency exchange rate appears due to fluctuation in currency during a longer time period. Since infrastructure projects are large-scale and complex projects, the implementation of these projects is lengthy and requires a longer period. While during a longer period, the currency exchange rate between the USD and the other currency is unstable with a lot of fluctuations. Hence, the currency exchange rate is a significant factor and the most critical factor which contributed to cost overruns in the majority of projects. A total of 20 overrun projects, 17 projects are located in China because the currency exchange rate between the US dollars and the Chinese Yuan was quite higher at the beginning than at the end of the project. Due to China's exchange rate reform in 2005, Chinese Yuan has been appreciated dramatically (Zhang \& Ouyang, 2018).

Complex geological and geotechnical conditions at the construction site are caused by geographically difficult terrain. Geotechnical differences between the detailed design 
and actual survey appear due to insufficient investigated geological conditions at the initial stage of projects. The majority of projects influenced by complex geological and geotechnical conditions were railway projects in China. In some projects, bad rock conditions at the site location have required additional reinforcement. While in other, landslides have occurred during the excavation process and it required land slope protection in order to assure security. Besides, environment protection measures, sustainability measures for tunnels and bridges, increased the cost of geological hazard mitigation and post-typhoon emergency work for drainage have contributed to cost overruns due to complex geological and geotechnical conditions of terrain.

Fluctuation in interest rate is a critical factor for determining debt intensity and the internal rate affects the whole-cycle of a project. Further, the inflation rate affects infrastructure projects, and it is one of the common risks in infrastructure projects (Wang, Dulaimi, \& Aguria, 2004). In the case of Regional Road Development project in Mongolia, the project was subjected to a high inflation rate which resulted in almost double than the planned budget (cost overrun was 96\%).

\section{Discussions}

The average cost overruns in Asia is 9.88\%, which is relatively small compared to worldwide with 28\% (Flyvbjerg et al., 2003a), Netherland with 16.5\% (Cantarelli et al., 2012a) and Hong Kong with 39.18\% (Huo et al., 2018). One of the reasons for lower cost overruns compared to other parts of the World is that energy sector projects are included in this study instead of fixed-links. Comparing the average cost overrun in different regions in Asia to worldwide, the highest mean value of cost overrun is $22.04 \%$ in East Asia, which is similar to the average cost overrun in Europe (26\%) and North America (24\%) (Flyvbjerg et al., 2002, 2003a, 2003b).

The cost overruns for rails projects is $21.11 \%$, which is lower compared to Europe (34.2\%), North America (40.8\%, Flyvbjerg et al., 2003a), and Hong Kong (58.08\%, Huo et al., 2018), but higher than Netherlands (10.6\%, Cantarelli et al., 2012b). Similarly, cost overruns for roads projects $(10.47 \%)$ are the lowest compared to Netherlands (18.6\%), Hong Kong (22.52\%) and Europe (22.4\%).

There is a correlation between cost overrun over a year of a decision to build and it is estimated that cost overrun decreases by approximately $1 \%$ over a year. This finding is not in line with findings from previous studies by Flyvbjerg et al. (2003a), Cantarelli et al. (2012b) and Huo et al. (2018). Similarly, this study shows a correlation between project size and cost overrun, the larger projects have higher cost overruns and smaller projects have lower cost overruns. This finding is in contrary with findings by Flyvbjerg et al. (2004) and Huo et al. (2018), in which is concluded that there is no correlation between two variables. However, Cantarelli et al. (2012b) and Odeck (2004) highlighted that there is a relation between project size and cost overrun, such as smaller size projects are exposed to higher cost overrun and larger projects have lower cost overruns which are opposing from findings in this study. Furthermore, there is a statistical relationship between implementation periods over cost overrun in this study, which is in line with conclusions by Flyvbjerg et al. (2004), Cantarelli et al. (2012b), and Huo et al. (2018). One of the explanations for differences in findings for cost overrun over a year of a decision to build and cost overrun over the project size for projects in Asia is that these projects are international development projects. There is a difference between development projects and industrial or commercial projects since the aim of development projects is to reduce the poverty, improve the living standards and environment, protect basic human rights, increase capacity and develop basic physical and social infrastructures (Ahsan \& Gunawan, 2010).

\section{Conclusions}

In this paper, the cost overruns in infrastructure projects in Asia are investigated, the influence of four variables project type, geographical location, project size and the length of implementation period on cost overruns are examined and determined, compared to other countries, and causes of cost overruns are identified. The conclusions which can be drawn from this study are as follows:

- Cost overruns in infrastructure projects in Asia are as common as cost underruns and the mean value of cost overrun (26.24\%) is higher than cost underrun $(-12.24 \%)$.

- Approximately, cost overruns in infrastructure projects in Asia decrease by $1 \%$ every year.

- Railway projects are more prone to cost overruns compared to roads and energy sector projects.

- East Asia is a region with the highest cost overrun in Asia since the majority of projects are railway projects, while projects in Central Asia are cost underrun.

- Regarding the project size, there is a statistical dependence between project size and cost overruns. Also, this correlation exists for all types of projects and East Asia and South Asia regions, when it is considered for different project types and geographical locations, separately.

- Regarding the length of the implementation phase, there is a correlation between cost overrun and the duration of the implementation phase. In addition, there is a statistical dependence for roads and rails projects, as well as South Asia and East Asia regions.

- The key causes of cost overruns are: increase cost of resources (construction materials, equipment, and labor), construction works, changes in design specifications, land acquisition and resettlement, and changes in currency exchange.

The performance of infrastructure projects and characteristics of cost overruns in Asia is significant information for governments, investors, contractors, $\mathrm{ADB}$ and others who are planning to participate in the construction of 
future development projects in Asia. Additionally, information about the key causes of cost overruns is important for project managers in order to prepare efficient plans and strategies to mitigate potential risks in future development projects.

For further studies, authors will conduct research on the performance of infrastructure projects in terms of time and delays, the influence of four variables from this study on time overruns in these projects, as well as causes of delays. The second direction is that cost overruns in other types of infrastructure projects, such as airports, sea ports, water supply systems, and others could be included in the database in order to provide more detail picture about the performance of infrastructure projects.

\section{Acknowledgements}

This research was supported by National Natural Science Foundation of China (project ID 71272088) and China Postdoctoral Science Foundation (grant number 2017M622743).

\section{Funding}

This work was supported by the National Natural Science Foundation of China under Grant [number 71272088]; and <China Postdoctoral Science Foundation $>$ under Grant [number 2017M622743].

\section{Author contributions}

The conceptualization of the research is carried out by Jelena M. Andrić, Jiayuan Wang, Patrick X. W. Zou and Ruoyu Zhong. Data collection, methodology and data analysis is conducted by Jelena M. Andrić. Writing the drafts of the article is carried out by Jelena M. Andrić and Abdul-Majeed Mahamadu. The funding is provided by Jiayuan Wang and Jelena M. Andrić.

\section{Disclosure statement}

Nothing to declare.

\section{References}

Adu, P. (2015). When to utilize manual coding or softwareaided coding such as NVivo. Retrieved from https://www. slideshare.net/kontorphilip/qualitative-data-analysis-whento-utilize-manual-coding-or-softwareaided-coding-such-asnvivo-56347603

Ahsan, K., \& Gunawan, I. (2010). Analysis of cost and schedule performance of international development projects. International Journal of Project Management, 28(1), 68-78. https://doi.org/10.1016/j.ijproman.2009.03.005

ADB. (2019). Asian Development Bank. Retrieved from https://www.adb.org/

Cantarelli, C. C., Molin, E. J., van Wee, B., \& Flyvbjerg, B. (2012a). Characteristics of cost overruns for Dutch transport infrastructure projects and the importance of the decision to build and project phases. Transport Policy, 22, 49-56. https://doi.org/10.1016/j.tranpol.2012.04.001

Cantarelli, C. C., van Wee, B., Molin, E. J., \& Flyvbjerg, B. (2012b). Different cost performance: different determinants? The case of cost overruns in Dutch transport infrastructure projects. Transport Policy, 22, 88-95. https://doi.org/10.1016/j.tranpol.2012.04.002

Cantarelli, C., Flyvbjerg, B., \& Buhl, S. L. (2012c). Geographical variation in project cost performance: the Netherlands versus worldwide. Journal of Transport Geography, 24, 324-331. https://doi.org/10.1016/j.jtrangeo.2012.03.014

Cantarelli, C. C., Flybjerg, B., Molin, E. J., \& van Wee, B. (2013). Cost overruns in large-scale transportation infrastructure projects: Explanations and their theoretical embeddedness. European Journal of Transport Infrastructure Research, 10(1), 5-18.

Ellis, Jr. R. D., Pyeon, J. H., Herbsman, Z. J., Minchin, E., \& Molenaar, K. (2007). Evaluation of alternative contracting techniques on FDOT construction projects (Final Report). Florida Department of Transportation.

El-Sayegh, S. M., \& Mansour, M. H. (2015). Risk assessment and allocation in highway construction projects in the UAE. Journal of Management in Engineering, 31(6), 04015004. https://doi.org/10.1061/(ASCE)ME.1943-5479.0000365

Flyvbjerg, B., Skamris Holm, M. S., \& Buhl, S. (2002). Underestimating costs in public works projects: Error or lie? Journal of the American Planning Association, 68(3), 279-295. https://doi.org/10.1080/01944360208976273

Flyvbjerg, B., Skamris Holm, M. K., \& Buhl, S. L. (2003a). How common and how large are cost overruns in transport infrastructure projects? Transport Reviews, 23(1), 71-88. https://doi.org/10.1080/01441640309904

Flyvbjerg, B., Bruzelius, N., \& Rothengatter, W. (2003b). Megaprojects and risk: An anatomy of ambition. Cambridge: Cambridge University Press. https://doi.org/10.1017/СBO9781107050891

Flyvbjerg, B., Skamris Holm, M. K., \& Buhl, S. L. (2004). What causes cost overrun in transport infrastructure projects? Transport Reviews, 24(1), 3-18. https://doi.org/10.1080/0144164032000080494a

Flyvbjerg, B., Ansar, A., Budzier, A., Buhl, S., Cantarelli, C., Garbuio, M., Glenting, C., Skamris Holm, M., Lovallo, D., Lunn, D., Molin, E., Rønnest, A., Stewart, A., \& van Wee, B. (2018). Five things you should know about cost overrun. Transportation Research Part A: Policy and Practice, 118, 174-190. https://doi.org/10.1016/j.tra.2018.07.013

Huo, T., Ren, H., Cai, W., Shen, G. Q., Liu, B., Zhu, M., \& Wu, H. (2018). Measurement and dependence analysis of cost overruns in megatransport infrastructure projects: Case study in Hong Kong. Journal of Construction Engineering and Management, 144(3), 05018001.

https://doi.org/10.1061/(ASCE)CO.1943-7862.0001444

Lee, J. K. (2008). Cost overrun and cause in Korean social overhead capital projects: Roads, rails, airports, and ports. Journal of Urban Planning and Development, 134(2), 59-62. https://doi.org/10.1061/(ASCE)0733-9488(2008)134:2(59)

Love, P. E., Sing, C. P., Wang, X., Irani, Z., \& Thwala, D. W. (2014). Overruns in transportation infrastructure projects. Structure and Infrastructure Engineering, 10(2), 141-159. https://doi.org/10.1080/15732479.2012.715173

Love, P. E., Zhou, J., Edwards, D. J., Irani, Z., \& Sing, C. P. (2017). Off the rails: The cost performance of infrastructure rail projects. Transportation Research Part A: Policy and Practice, 99, 14-29. https://doi.org/10.1016/j.tra.2017.02.008 
Makovšek, D., Tominc, P., \& Logožar, K. (2012). A cost performance analysis of transport infrastructure construction in Slovenia. Transportation, 39(1), 197-214. https://doi.org/10.1007/s11116-011-9319-z

Merrow, E. W. (2011). Industrial megaprojects: concepts, strategies, and practices for success (Vol. 8). Hoboken, NJ: Wiley.

Odeck, J. (2004). Cost overruns in road construction - what are their sizes and determinants? Transport Policy, 11(1), 43-53. https://doi.org/10.1016/S0967-070X(03)00017-9

Park, Y. I., \& Papadopoulou, T. C. (2012). Causes of cost overruns in transport infrastructure projects in Asia: their significance and relationship with project size. Built Environment Project and Asset Management, 2(2), 195-216. https://doi.org/10.1108/20441241211280873

Qian, Z. (2015). Land acquisition compensation in post-reform China: Evolution, structure and challenges in Hangzhou. Land Use Policy, 46, 250-257. https://doi.org/10.1016/j.landusepol.2015.02.013

Shi, G., Zhou, J., \& Yu, Q. (2012). Resettlement in China. In Impacts of large dams: A global assessment (pp. 219-241). Berlin: Springer Heidelberg. https://doi.org/10.1007/978-3-642-23571-9_10

Terrill, M., \& Danks, L. (2016). Cost overruns in Australian transportation infrastructure projects. In Proceedings of Australasian Transport Research Forum 2016 (pp. 184-194). Melbourne, Australia.
Wang, S. Q., Dulaimi, M. F., \& Aguria, M. Y. (2004). Risk management framework for construction projects in developing countries. Construction Management and Economics, 22(3), 237-252. https://doi.org/10.1080/0144619032000124689

Wang, J. Y., \& Yuan, H. P. (2011). Major cost-overrun risks in construction projects in China. International Journal of Project Organisation and Management, 3(3-4), 227-242. https://doi.org/10.1504/IJPOM.2011.042030

Zeng, S. X., Tam, C. M., Deng, Z. M., \& Tam, V. W. (2003). ISO 14000 and the construction industry: survey in China. Journal of Management in Engineering, 19(3), 107-115. https://doi.org/10.1061/(ASCE)0742-597X(2003)19:3(107)

Zhang, T., \& Ouyang, P. (2018). Is RMB appreciation a nightmare for the Chinese firms? An analysis on firm profitability and exchange rate. International Review of Economics \& Finance, 54, 27-43. https://doi.org/10.1016/j.iref.2017.05.003

Zhao, X., Hwang, B. G., \& Yu, G. S. (2013). Identifying the critical risks in underground rail international construction joint ventures: Case study of Singapore. International Journal of Project Management, 31(4), 554-566.

https://doi.org/10.1016/j.ijproman.2012.10.014 